\title{
IMPROVING PUPILS' VOCABULARY MASTERY BY USING VIDEO SONGS
}

\author{
Nanda Ella, Sofian, Eni Rosnija \\ Program Studi Pendidikan Bahasa Inggris FKIP Untan Pontianak \\ Email:nandaella90@gmail.com
}

\begin{abstract}
The research was aimed to improve pupils' vocabulary by using video songs. This research was a classroom action research which done in two cycles. The subject of this research was the class A6 pupils of TK Immanuel. The researcher observed pupils' improvement by collecting data through field notes, observation checklist and vocabulary test. The pupils' behaviour towards the learning process was gathered by field note and observation checklist. The data of vocabulary was obtained by vocabulary test which was assessed through scoring rubric. The result showed those pupils' problems in recognizing and mentioning the vocabulary had been solved by using video songs as the media of teaching. Furthermore, pupils' interest in learning vocabulary also improved. It was shown by the pupils' enthusiasm to pay attention in watching the video and singing together during teaching and learning process. Finally, the media was able to be used in improving pupils' vocabulary.
\end{abstract}

Keywords: Video Songs, Vocabulary, Kindergarten, Transportation

To cite this paper (in APA style):

Ella, N., Sofian, Rosnija, E. (2021). Improving pupils' vocabulary mastery by using video songs. Journal of English Program, 2(1), 3948. http://dx.doi.org/10.26418/jeep.v2i1.44121

\section{INTRODUCTION}

Learning vocabulary is the foundation of learning language. Therefore, since vocabulary as a foundation in language learning can improve pupils' vocabulary mastery, it has become priority in education. Vocabulary is an important role in language learning, learning vocabulary will improve language skill quickly. Learning vocabulary will make pupils better able to master other skills such as reading, listening, speaking, and writing. In mastering vocabulary, pupils should master some elements of vocabulary, such as pronunciation of the word, spelling of the word, meaning of the word, and grammatical pattern of the word. Based on the observation in the class, the researcher established that the problem is most of students at Kindergarten A6 cannot mention and pronounce the vocabulary well in the learning activity. Sometimes, pupils know about the teacher said, but they 
cannot mention using English well. For example, when the teacher asked about the picture (car), some of pupils said "mobil".

Based on the interview with the teacher, she said that pupils in this age, they cannot focus to learn without any media to support the teaching process. Therefore, the researcher applied video songs as a media to teach vocabulary that can make pupils excited to learn. According to Murphey $(1992$, p.3) music is highly memorable and motivating especially for children. It implies that pupils can remember the words easily using song and music. It can also stimulate the pupils to learn more than usual. Songs use in classroom is a powerful technique in teaching and practicing vocabulary, grammar, listening, and speaking (Walker, 2006).

This school develops the curriculum for English subject. In this research, the theme of material that the researcher used was based on the syllabus, that is "transportation" in first semester. The researcher taught the vocabulary about transportation and asked students to sing together. The researcher did not teach how to write the vocabulary because its activity will be done on second semester. Moreover, the researcher played some songs related to the material such as "the wheels on the bus", "row-row your boat", and "up in a balloon". These video songs will be found in the youtube by channel "chu-chu tv", and "super simple song". To asses the pupils in mastering the vocabulary, the researcher gave achievement tests that are "listen and circle the transportation, listen and stick the correct picture and circle the pictures of transportation.

Formerly, there are some researchers who conducted research connected in applying video songs as the media in teaching and learning context. One of them is a research that conducted by Ningsih (a student of Tanjungpura University) with the title: "The use of song lyrics to improve students' vocabulary mastery at kindergarten one of town for kids preschools" (A classroom action research to kindergarten one of town for kids preschools). She found that, some strengths and weaknesses of using song lyrics in teaching vocabulary to kindergarten level as follows: (1). The teacher become closer to the pupils; (2). It stimulates pupils to engage actively in learning English; (3). The process of learning become more excited and build up the vocabulary background of pupils; (4) At the time pupils sing the song, they will look at the picture and listen the song to learn the meaning and how to pronounce the vocabulary well; (5). It assists the pupils' brain to learn the vocabulary untroubled. The weaknesses of using song lyrics as the teaching media as follows: (1). Not all of pupils can enjoy the song, especially the pupils who do not like to sing; (2). Conducting this research should be done by more than one person, it needs a collaborator to help. This research is going to be different from the previous research in terms of applying the media in teaching activity. Based on the problem of pupils in mastering the vocabulary, the researcher conducted a classroom action research which use video songs as the media to solve this problem. 
Through classroom action research, the researcher proved that video songs can improve pupils' vocabulary mastery at TK Immanuel Pontianak in academic year 2019/2020. The researcher conducted classroom action research because it is a method of finding out what technique or media best in the classroom that teacher can improve pupils learning vocabulary. The researcher conducted this research in Kindergarten in level A, that is class A6. This class consists of 24 pupils and 2 teachers. The researcher as the teacher in this class and the collaborator is Miss Vini as a head level for Kindergarten level A in TK Immanuel Pontianak.

\section{METHOD}

In this research, the researcher conducted classroom action research. Classroom action research is research that conducted in the classroom aim to know problem that happen in the classroom specially students' understanding about subject that is taught by teacher. The process of this action research had four components in one cycle. They are planning, acting, observing, and reflecting. According to Burns (2010) four main components of classroom action research can be describes as follows:

Planning: In this stage, the researcher and the teacher discussed and made a plan about how the media should be conducted and what is needed in implementing this media. In making the lesson plan, the researcher and the teacher prepared the learning material, learning media, and the assessment. The researcher prepared the observation checklist and field notes in this stage.

Acting: In the second stage, the researcher conducted the teaching learning process in the classroom where the problem appeared. In this stage, the researcher acted as the teacher. The lesson plan is followed in applying the process of teaching and learning in the classroom. There will be three parts in meeting of actual classroom teaching activity. It consists of pre-activity, whilst-activity, and post-activity. In the pre-activity the teacher greeted the students, check the students' attendance, and give motivating strategy by asking some questions related to material. In the whilstactivity, the teacher played the video songs related to the material and asked students to sing together. In the post-activity, the teacher asked the students about the vocabulary related to the material by using pictures. In this occasion, the collaborator took note in the form of field notes and filled observation checklist that has been prepared.

Observing: The collaborator did the observation during the process of teaching and learning activity, the implementation of using video songs and how pupils and the researcher behaved and whether or not the use of video songs could improve the achievement in that class. The results of the observing were noted in field notes and observation checklist.

Reflecting: The last stage, the researcher evaluated and described the outcome of the use of the media in sequence to be clear of what has happened and to recognize 
the point they have investigated more totally. In this stage, the researcher shared, analysed, and evaluated the information which are obtain from the classroom observation activities and the notes taken to get feedback on what have done. Belonging to the analyses, the researcher acquired some valuable comments. This is used in re-planning the following action. It may be changed a defined activity or build on more activity orderly to enhance teaching learning procedure.

\section{Research Participants and Setting}

In this research, the researcher obtained the A6 pupils of TK Immanuel 1 Pontianak located on Jln. Gajahmada No. 250. In the class, there are 13 male pupils and 11 female pupils. Based on the observation before, the researcher established that pupils of TK A6 had weak of vocabulary which made the learning targets cannot achieved absolutely. Thus, the researcher chose this class to assist the pupils in improving vocabulary.

\section{Techniques of Data Collection}

The researcher acquired the data through observation and measurement techniques. The observation is finished by applying observation checklist sheet and field notes as a direction to see pupils' improvement by using video songs. Meanwhile, measurement technique is done by conducting vocabulary written and oral test to perceive the progress or achievement of pupils in each cycle.

\section{Tools of Data Collection}

Observation Checklist Sheet: The observation checklist functioned as a reflecting for the upcoming stage. It includes a set of statement that evaluate the performance and behaviour of teacher and pupils in a classroom setting, how the teacher explained the materials and used the media of teaching, the behaviour from the pupils and also how the pupils' work in doing the test.

Field Notes: In this tool, the collaborator noted and listed anything happened when conducted the research. Field notes are used to put down the pupils' activities, progression, weaknesses and obstacles in each meeting.

Achievement Test: The first achievement test is oral test, pupils were asked to mention the name of transportation. The second achievement, pupils were asked to listen then circle the correct picture. And the last achievement test, pupils were asked to circle the pictures of transportation. 
JEEP-ISSN 2721-6896

http://dx.doi.org/10.26418/jeep.v2i1.44121

Table 1. Scoring table form ( $1^{\text {st }}$ and $2^{\text {nd }}$ cycle)

\begin{tabular}{cc}
\hline Number of Correct Answer & Classification \\
\hline 5 & Excellent \\
\hline 4 & Good \\
\hline 3 & Fet improved \\
\hline 2 & Keep learning \\
\hline 1 & Poor
\end{tabular}

FINDINGS AND DISCUSSION

\section{Research Findings}

The researcher calculated the individual pupil's score based on the achievement test, then calculated the pupils' individual and mean score. Then, the researcher detailed the result of mean score and recorded of field note in place to attain the disparity in the research findings.

The use of video songs improved pupils' vocabulary mastery in the aspect of pronunciation

The researcher always started the teaching and learning process by singing together in every meeting. During teaching and learning process, the researcher showed some pictures that related to the material and asked pupils to repeat after the researcher. After that, pupils watched the video songs related to the material. Then, the researcher asked the pupils to mention the vocabulary based on the pictures. Those activities engaged the pupils' attention to learn in pronouncing the words correctly.

The use of video songs improved pupils' vocabulary mastery in the aspect of meaning

In applying video songs use as the media in teaching vocabulary, the researcher asked pupils about the meaning of the pictures by pointing the pictures based on the instruction. Moreover, the researcher put the pictures around the classroom and asked pupils to find the pictures based on the instruction. It works to attracted pupils' attention and motivation to learn the meaning of vocabulary they learnt.

Cycle 1 (October 16 th $^{\text {2019) }}$

Planning: This cycle designed in one meeting. Time allocation was 50 minutes. The pupils learnt about the vocabulary of transportation. The tools are pupils achievement test, observation checklist, and field note.

Acting: The researcher acted as a teacher and the English teacher as the collaborator. There was one pupil absent on that day. The researcher implemented video songs 
as the media of teaching in order to improve pupils' vocabularies of transportation. The researcher began the teaching and learning process by greeting and singing together. The researcher asked pupils to sing as the brainstorming. After that, the researcher showed the flashcards of transportation and put it on the white board. The researcher mentioned the vocabularies and the pupils repeated it. To analyze the achievement, the researcher asked pupils to choose the flashcard based on the instruction. Then, the researcher prepared the laptop, LCD, and speaker. The pupils enjoyed the video songs and most of them watched it seriously. The video songs played repeatedly to help pupils more understand and remember about the vocabularies. After watch the video song, the researcher gave achievement tests. The first achievement test was about listen then circle the correct picture, and the second was circle the pictures of transportation. The researcher ended the class by singing together. This activity could help pupils to remember what they have learnt.

Observing: The researcher and the collaborator noticed the outcome of first stage. They observed all process of the first cycle by using observation checklist and field notes. Beyond observing the whole process and pupils' contribution, they struggled to relate the strengths and weaknesses of this media. From the data taken by observation checklist and field notes, it was found the pupils were enthusiast when they were implementing video songs as a media of learning by giving them to look at the pictures, mention it together, watch the video songs, and sing together. The pupils also were active to mention the vocabulary of transportation by looking the pictures, active to sing the songs related to the material and enjoy watching the video songs.

Reflecting: In this stage, the collaborator and the researcher considered what had been done in the first cycle. The researcher made summary of the problems and weaknesses in this cycle. Then the researcher discussed about the solutions and adds another action in order to correct the problems that happened, so the teaching learning process, as well as the pupils' achievement can be improved.

Depend on the consultation between the researcher and the collaborator, it could be decided the first cycle had been good but they still required attempt to carry out the goal of the media used but the pupils were improving, are as follows:

Most of the pupils are able to recognize the vocabulary transportation correctly. The pupils are not able to mention the names of the vocabulary correctly. Some of pupils are not able to understand the instruction of the achievement.

\section{Cycle 2 (October 23rd 2019)}

Planning: In the first cycle, the researcher and the collaborator found that the pupils are still difficult to mention the names of vocabulary correctly. They looked forget about the vocabulary, so they just mention in Indonesian or silent. The researcher and the collaborator made effort to cover the shortcomings come off in the last cycle. 
The lesson plan, teaching media, observation checklist and field notes are prepared by them.

Acting: On October 23rd, 2019 the researcher and the collaborator directed the second cycle. Two pupils were absent on that day. The researcher started the lesson by greeting them and singing together. The researcher asked pupils to sing as the brainstorming. After that, the researcher showed the flashcards of transportation and put it on the white board. The researcher mentioned the vocabularies and the pupils repeated it. To analyze the achievement, the researcher asked pupils to choose the flashcard based on the instruction. Then, the researcher prepared the laptop, LCD, and speaker. The pupils enjoyed the video songs and most of them watched it seriously. The video songs played repeatedly to help pupils more understand and remember about the vocabularies. After watch the video song, the researcher gave achievement tests. First achievement test, pupils were asked to listen and stick the pictures and the second achievement tests, pupils were asked to circle the pictures of transportation. The last activity was singing together to review the material.

Observing: The researcher and the collaborator observed the outcome of acting stage. All process of the first cycle was observed by using observation checklist and field notes. By observing the whole process and the pupils' contribution, they attempted to connect the strengths and weaknesses of this media. From the data taken by observation checklist and field notes, it was found the pupils were enthusiast when they were implementing video songs as a media of learning by giving them to look at the pictures, mention it together, watch the video songs, and sing together. The pupils also were active to mention the vocabulary of transportation by looking at the pictures, active to sing the songs related to the material and enjoy watching the video songs. Pupils' reaction to the teaching and learning vocabulary process during showed good progression from first cycle to second cycle, it showed by the pupils' behavior of being more active to answer the teacher's question about the vocabulary they learnt, doing the achievement tests and mention the vocabulary correctly.

Reflecting: In this second cycle of reflecting, the researcher and collaborator assumed that the use of video songs could improve pupils' vocabulary especially vocabulary of transportation. This was because based on observation checklist and field notes which were filled by the collaborator and the result of achievement tests, it was found that the learning process was satisfied. The pupils' achievement tests also continued to rise. It can be concluded that the use of video songs was clearly effective as teaching media for vocabulary mastery.

\section{DISCUSSION}

In general, the effect of the research showed the improvement by implementing of video songs in the process of teaching and learning. Most of pupils actively contributed in singing songs, watching video songs, and mentioning the vocabulary. 
The result support Ningsih (2018) research that when pupils sing the song, they will learn the meaning of vocabulary and how to pronounce it correctly by looking at the picture of the song. It also encourages pupils' brain to know the vocabulary meaning unworriedly. It can be seen that the pupils seemed to enjoy when the pupils asked to sing the songs, watch the video songs and finally could mention the names of transportation. The pupils were loving their lesson delivered by the researcher. In the first cycle, some of pupils recognized the names of vocabulary well. But in this cycle, they difficult to mention the vocabulary correctly. The researcher gave them some video songs about transportation and they looked enthusiast. In doing achievement tests, there were six pupils could not do it perfectly.

In the second cycle, most of pupils could mention the names of vocabulary correctly. There were three pupils difficult to mention the vocabulary correctly. In doing achievement tests, the researcher changed the achievement into stick the picture and there are two pupils could not do it correctly. They did not understand what the researcher said in teaching process. In this cycle, pupils were more active and felt excited during the lesson. Since, all pupils could finish the activities and the researcher gave the chance to find the pictures as instructed. And it worked well to motivate them to study. Then, the finale of the activity, the researcher and the collaborator concluded the materials. After observing the process and interpreting the data, both the researcher and the collaborator decided to stop the actions because the data showed that the goal was achieved successfully. The pupils become very motivated to sing especially if the song is familiar and related to material lesson. Songs also may inspire creativity and use of imagination in a relaxed classroom atmosphere. To use this media in teaching, the teacher should consider the theme and the rhythm when they select the song. The song should be appropriate with the topic of the English lesson and attract the pupils' attention.

In short, the research findings of the classroom action research were satisfying. The pupils' vocabulary is improved by implementing the video songs as a media of teaching and learning process. The pupils can recognize the vocabulary of transportation and can mention the names of vocabulary correctly.

\section{CONCLUSION AND SUGGESTIONS}

\section{Conclusion}

From the discussion in the last chapter, it could be terminated that pupils' vocabulary in class A6 of TK Immanuel Pontianak in academic year 2019/2020 improved by applying the video songs as a media of teaching and learning. In applying the video songs, the teacher played the videos repeatedly and all of pupils were watching the video and singing together, mentioning the names of vocabulary in terms of "transportation", pointing the picture as instructed and doing some exercise to measure the ability of the pupils. The improvement of pupils' vocabulary in class A6 can be seen by the first and second cycle of the process of teaching. The
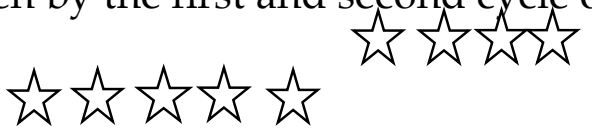
termination of the first cycle was good (

) while the result of the second cycle was excellent (

). The use of video songs as the media in teaching vocabulary was able to make pupils active in learning process. As well, the use of video songs can supply highest opportunity to create active pupils in learning vocabulary. Pupils are able to sing the songs, recognize the names of transportation, and mention the names of vocabulary correctly. Once, they were hesitating to mention the names of transportation and now they are able to mention it.

\section{SUGGESTION}

The researcher provides the suggestions drawn from the result of this research, improving pupils' vocabulary mastery by using video songs at A6 class of TK Immanuel Pontianak in Academic Year 2019/2020. (1) In using video songs as a media of teaching to reach the goals, teachers demand to apply it in engrossing and acceptable activity. (2) The researcher suggested the English teacher to apply video songs in teaching vocabulary in order to make pupils more active and excited to learn vocabulary through sing the songs, watch the video songs and finally mention the vocabulary correctly. (3) The use of video songs can be concern for all kinds of the vocabulary with variant topic in English lesson. This media can be appropriate with the pupils' level, pupils' culture and also curriculum that the school uses. The main goal of this media is to help the teacher to teach interestingly. The use of video songs in teaching process is more helpful in order to deliver the teaching material for pupils. (4) For using video songs as the media of teaching, teacher also can use other media that is interesting pictures. Pictures can help pupils remember the vocabulary. (5) This media can be a device for the pupils for getting their learning attainment. The teacher has to lead them intensively in teaching and learning process. The class managing can indirectly assist the pupils to center with the teaching process.

\section{REFERENCES}

Asih, N. (2011). The effectiveness of using pictures and songs in teaching vocabulary to young learners. Gunadarma University Library. Retrieved November 18, 2012, from:

http:// papers.gunadarma.ac.id/index.php/letter/article/view/16970/161 51

Burhayani, E. (2013). The effectiveness of teaching vocabulary through songs to the second years students of Ikatan Keluarga Kesejahteraan Tentara (IKKT) Elementary School West Jakarta. 2nd International Seminar on Quality and Affordable Education, (ISQAE 2013). 70-73.

Burns, A. (2010). Doing action research in English language teaching. New York: Routledge. 
Farrah, A. M. \& Shehadeh, A Iman. (2016). The effectiveness of using children's songs in developing elementary graders' English vocabulary and pronunciation in Jerusalem, Palestine. Journal of Creative Practices in Language Learning and Teaching (CPLT). Volume 4, Number 2.

Gairns, Ruth \& Redman, Stuart. (1986). Working with words: a guide to teaching and learning vocabulary. Cambridge: United Kingdom.

Hiebert, Elfrieda H. \& Kamil, Michael L. (2005). Teaching and learning vocabulary bringing research to practice. Lawrence Erlbaum Associates: London.

Kemmis, Stephen \& Mc. Taggart Robbi. (1990). The action research planner. Australia: Deakin University.

Mettetal, G. (2001). The what, why and how of classroom action research. The Journal of Scholarship of Teaching and Learning. Indiana University.

Neuman, Susan B. \& Wright Tanya S. (2014). The magic of words:teaching vocabulary in the early childhood classroom. American Educator.

Qurt, D. (2013, May). Learning vocabulary through songs. Paper presented at British Council Organising Better Learning Programme Conference, Dar Al-Kalima College, Bethlehem, Palestine.

Sevik, M. (2011). Teacher views about using songs in teaching English. Educational Research and Review, 6(21),1027-1035. doi:10.5897/ERR11.250. Retrieved May 15, 2013 from:

http:/ / www.academicjournals.org/err/PDF/Pdf\%202011/12Dec/Sevi k.pdf

Thiruvengadam, P. (2018). A review of vocabulary teaching techniques for young learners. SCSVMV University.

Wang, Z. (2015). An analysis on the use of video materials in college English teaching in China. International Journal of English Language Teaching. Vol 2.

Wrenshall, J. (2002). Using song to Improve Communication Competence. Bangkok: November. AUA Language Center., p.43. 